Ayurlog: National Journal of Research in Ayurved Science http://www.ayurlog.com Volume: $6^{\text {th }} \mid$ Issue: $5^{\text {th }} \mid$ August 2018

\title{
A clinical study- management of Arma with Nayansukhavarti Anjan
}

\author{
Yogesh Kumar Sisodiya*1 ${ }^{1}$ Tushar Firke ${ }^{2}$
}

\section{PG Scholar,}

\section{Professor and HOD}

\section{Dept. of Shalakya Tantra, SMBT Ayurved College \& Hospital,}

\author{
Dhamangaon, Nashik, Maharashtra
}

\section{*Corresponding Author: Email : vdyogeshsisodiya1988@gmail.com}

(Pradhan karma) after Deepan-pachan \& Nasya karma (Poorvakarma) and shamana

\begin{abstract}
:
Eyes are the most sensitive and vulnerable part of our body. Air born infection, UV rays, pollutants, dust and other particles can land directly on the surface of eye: causing eye disease. Arma is defined as gradually developing continuous wing like growth in shukla mandla from either Kaninika sandhi (inner canthus) or Apang sandhi (outer canthus) towards Krishna mandala, causing discomfort in eye. Pterygium found in people residing tropical and subtropical area. Risk factor included outdoor work, exposure to sunlight, dry and dusty climate etc. Due to geographic and climatic condition Pterygium is common ocular disorder in India. The Ayurvedic science can be explored to find a better alternative to manage this condition. Arma which is in early stage having thin membrane and curd like bluish/ red coloured and smoky should be treated by lekhana anjan and recurrence rate is very rare after anjana kriyakalpa. So considering all facts Nayansukha varti anjana selected for Arma chikitsa. In present study 10 patients of Arma were selected and administered Nayansukha varti anjana
\end{abstract}

chikitsa with triphala churna. Nayansukha varti anjana have lekhaniya and rasayana property which is useful in Arma chikitsa. * significant relief was found in signs \& symptoms of Arma after the treatment and no any adverse effect found after treatment. Drugs used in treatment are easily available drugs and cost effective.

\section{Keywords:}

Arma, Pterygium, Nayansukhavarti anjana

\section{INTRODUCTION:}

Eyes are the most sensitive and vulnerable part of our body. Air born infection, UV rays, pollutants, dust and other particles can land directly on the surface of eye, causing eye disease. Sushruta mentioned eleven types of Shuklagata rogas (white part of eye) in which Arma is also one shuklagata roga. It is defined as gradually 
developing continuous wing like growth in shukla mandla from either Kaninika sandhi(inner canthus) or Apang sandhi (outer canthus) towards Krishnamandala, causing discomfort in eye. It is common in shalakya practice. As per Ayurvedic classics on the basis of signs and symptoms Arma can be correlated with pterygium in modern science.

Pterygium is triangular shaped fibrovascular sub epithelial in growth of degenerative bulbar conjunctival tissue over the limbus on cornea which is hyper plastic condition of conjunctiva. The sub conjunctival tissue is undergoes elastic degeneration and proliferates as vascular granulation tissue under the epithelium which is ultimately enchroches the cornea. The common etiology of netra roga can be considered as etiology of Arma specially Swedadidhum nishewana (sweating, exposure to dust, smoke etc.) cause locally khavagunya (locally erosion and irritation) and other etiology apthaya aahara vihara cause vitiation of doshas which further reach at khavagunya site (weak place) where dosha-dushya samoorchana take place and clinical features appear.

Pterygium found in people residing tropical and subtropical area. Risk factor included outdoor work, exposure to sunlight, dry and dusty climate etc. Prevalence is high in factory workers than in office worker, higher in rural area than city. Due to geographic and climatic condition Pterygium is common ocular disorder in India.

In modern science treatment of Pterygium is surgical removal of enlarged part of conjunctiva but recurrence is more after surgery Hence, the Ayurvedic science can be explored to find a better alternative to manage this condition. Treatment of Arma described in Ayurvedic text both medical and surgical. Arma which is in early stage having thin membrane, curd like bluish/ red coloured and smoky should be treated by lekhana anjana. In Ayurveda there are three types of anjana are described which re Lekhana anjana (for kapha dominant dosha), Ropana anjana (for pitta dominant dosha), Prasadana anjana (for vata dominant dosha). Arma is type of mamsavridhi and all type of mamsa vridhi is kaphatmaka so lekhna ajana treatment is good for Arma. So considering all facts Nayansukha varti anjana selected for Arma chikitsa. Nayansukha varti anjana have lekhniya and rasayaniya property which is useful in Arma chikitsa. This is very easly available drug and cost effective.

\section{METHODOLOGY -}

In this present study, Line of treatment is cure disease with tridosha shamana. In the 
early stage of Arma Lekhana karma is indicated. Lekhana karma can be done by using lekhana anjana. Hence present study is aimed to establish an appropriate therapy which is very less irritative to eyes and relieve the symptoms of disease.

\section{TREATMENT PROTOCOL FOR}

ARMA CHIKITSA-As per principal of aushadh sadhya Arma chikitsa, Aacharya Vagbhatta described as -

\section{Armokt Panchdha Tatra Tanu}

Dhumavilam Cha Yata /

Raktam Dadhinibham Yaccha

Sukravattasya Bhesajam //

(Astanga Hridaya Uttartantra. 11/13)

\section{STUDY PLAN -}

Total 10 patients suffering from Arma were selected by clinical examination in OPD \& IPD department of shalakyatantra. Many type of treatment described for Arma chikitsa in Ayurvedic samhitas but I had selected treatment for Arma as follow-

\section{POORVA KARMA -}

- Firstly deepana pachana with chitrakadi vati (2 tabs BD) for three days.

- Nasya karma - Mukhabhayanga and mriduswedana done before shodhana nasya. Anu taila used for shodhana nasya karma (4-5 drop in each nostrils) for next 3 days.

\section{PRADHANA KARMA -}

- Anjana kriyakalpa with Nayansukha varti anjana advised for 15 days.

\section{Shamana Chikitsa -}

- Triphala churna was advised as shamana chikitsa 5 gm HS with normal water for 30 days (after poorva karma).

Nayansukha Varti Anjana :-

Ekgunamagdhika Dwigunach

Haritaki Salilpista /

\section{Vartireyam}

Nayansukhatimirarmapatalkanchashruh ari//

(Chakradutta netra roga chikitsa 59/121)

When doshas are localized in eyes than after Anjana is applying, Anjana is apply in comfort position of patient (supine position) by shalaka from inner canthus to outer canthus, After anjana karma patient advised to closed his eyes gently and rotate them in all direction so as to disperse anjana uniformly in eyes. This process was repeated daily morning for fifteen days. 


\section{EXAMINATION -}

Patients were examined in detail as per Ayurvedic and modern method. On slit lamp examination very short triangular fold of conjunctiva enchroches near the cornea in the area of palpebral aperture.

\section{Inclusion criteria-}

- Patients between the age of 20 to 50 years selected.

- Patients having classical lakshana of Arma.

- Arma which can be treated medically as per ayurvedic samhitas were selected.

- Duration of disease less than one year.

\section{Exclusion criteria -}

- Patients less than 20 years and above 50 years.
- Duration of disease more than one year.

- Arma associated with other occular disorders and systemic complication.

- Patients' anahara for Anjana i.e patients with Chedya and Asadhya Arma as per ayurvedic samhitas were excluded.

- Arma reaches to pupillary region and effect on visual acuity.

\section{Assessment criteria -}

Assessment was done on the bases of clinical signs and symptoms in patients. For this purpose main clinical signs and symptoms were given with suitable scores according to their severity before, during and after treatment.

\begin{tabular}{|l|l|}
\hline Rakta (vascularity) & 0-Absent \\
& 1-Mild with unidirectional pattern \\
& 2-Moderate with unidirectional and enlarged vessels \\
& 3-Marked with unidirectional and engorged vessels \\
\hline Mamsa vridhi on shukla & 0-Absent \\
mandala & $\begin{array}{l}\text { 1-Mild mamsa vridhi on limbus } \\
\text { 2-Encroach cornea up to } 1 \mathrm{~mm} \text { from limbus } \\
\text { 3- Encroach cornea> } 1 \mathrm{~mm}\end{array}$ \\
\hline Photophobia & $\begin{array}{l}\text { 0-Absent } \\
\text { 1-Sensitivity to bright sunlight and other bright stimulus }\end{array}$ \\
\hline
\end{tabular}




\begin{tabular}{|l|l|}
\hline & $\begin{array}{l}\text { 2-Sensitivity to mild sunlight but comfortable in dim light } \\
\text { 3-Sensitivity to even dim light with inability to open eyes }\end{array}$ \\
\hline Foreign body sensation & $\begin{array}{l}\text { 0-Absent } \\
\text { 1-Occasionaly present } \\
\text { 2-Frequently present with lacrimation } \\
\text { 3-Continuous present with lacrimation and congestion }\end{array}$ \\
\hline
\end{tabular}

- Follow up after the treatment, all patients were advised to attend the OPD for one month at regular interval for fifteen days .

\section{1- RESULT-}

\begin{tabular}{|l|l|l|l|l|l|l|}
\hline \multirow{2}{*}{$\begin{array}{l}\text { Sr. } \\
\text { No. }\end{array}$} & \multirow{2}{*}{ Parameters } & \multicolumn{2}{|c|}{ Mean \pm SD } & \% relief & "t" Value & "p" \\
\cline { 3 - 4 } & & Before treatment & After treatment & & & Value \\
\hline 1. & Ragta & $2.400 \pm 0.5164$ & $0.900 \pm 0.9944$ & 62.5 & 6.708 & $<0.001$ \\
\hline 2. & Mamsa vridhi & $2.600 \pm 0.5164$ & $1.500 \pm 0.7071$ & 42.3 & 6.128 & 0.02 \\
\hline 3. & Photophobia & $1.800 \pm 0.6325$ & $0.700 \pm 0.4830$ & 61.1 & 6.128 & $<0.001$ \\
\hline 4. & F.B. Sensation & $1.900 \pm 0.3162$ & $0.700 \pm 0.8233$ & 63.1 & 4.811 & $<0.001$ \\
\hline
\end{tabular}

Data 1

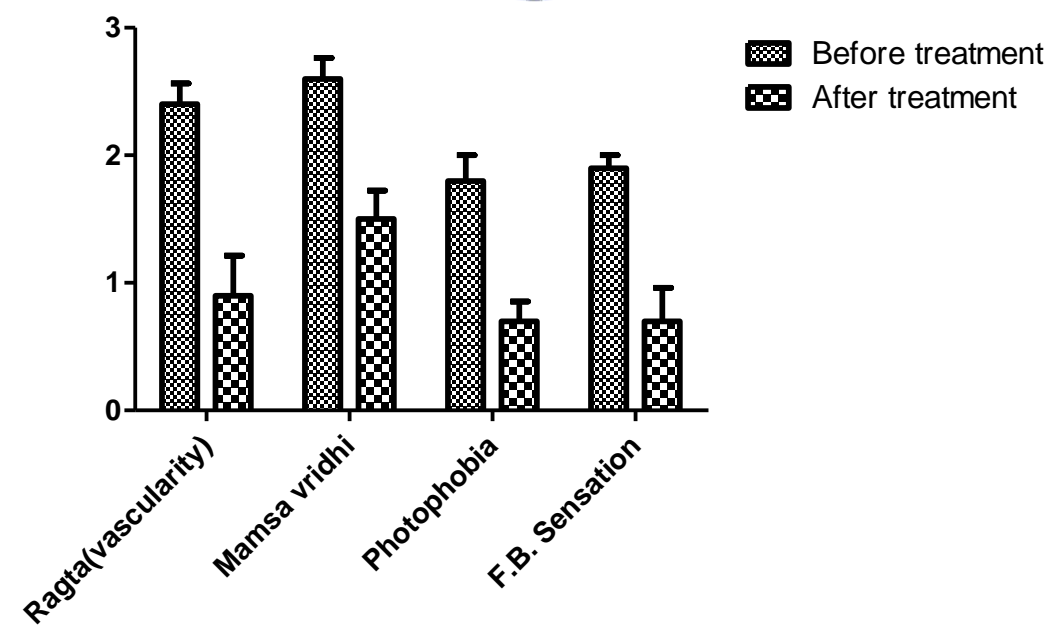

The scoring of criteria of assessment was analyzed statistically in term mean value of before treatment (B.T.), after treatment (A.T.), standard deviation. Various observation made and result obtained were computed statistically using on graphpad instat software. Result of 10 patients shorted that symptomatic improvement was considerable in all parameters of Arma. 
It has been observed that symptoms like Ragta shows changes in mean value from 2.4 to 1.5 showing a reduction of $1.5(62.50$ $\%$ relief ), Mamsa vridhi shows changes in mean value from 2.6 to 1.5 showing a reduction of $1.1(42.30 \%$ relief $)$, photophobia shows changes in mean value from 1.8 to 0.7 showing a reduction of $1.1(61.11 \%$ relief), Foreign body sensation shows changes in mean value from 1.9 to 0.7 showing a reducton of $1.2(63.15 \%$ relief) which are all statistically significant.

\section{DISCUSSION:}

- Deepana pachana- Medicine will act on body like amrita when there niramawastha. Deepana pachana drug help to achieve this state. Due to ushna and laghu guna of deepana pachana drugs enhance agni and aam pachan occurs and facilitate easy digestion.

- Also Nasya karma is good for urdhva jatrugata rogas and according to ayurveda nose is designated as gateway of cranial cavity. By Nasya karma administered drug reaches in sringataka marma through nasa, spread to siras (arterioles) of head, netra (eyes), karna (ears), kantha (throat) and expelled out vitiated dosha from the uttamanga. Shodhana nasya was administered with anu taila before giving Anjana kriyakalpa.

- Anjana is one among the kriyakalpa, the occular therapeutic which are pillar of shalakya tantra. In treating the disorders of eyes many topical treatment are explained in our classics along with systemic procedure. It assumed that they possess the potency to target tissue involve in pathology.

- Nayansukha varti anjana was used here and effective in subsiding lakshana of Arma like ragta, FB sensation and photophobia. It acts on occular tissue especially on conjunctiva, therefore will be helpful in conjunctival disorders. The medicine through anjana which are hydrophilic, gets absorbed through conjunctiva and even conjunctiva is hydrophilic because of its waterbase and the action of drug like anti-inflammatory are achieved through this route.

- Through lekhana anjana kriyakalpa, vitiated dosha situated in vessels of eyes, eyelids, cavity and channels of eye (srotas) are drained out through mouth, nostrils and eyes. Nayansukha varti anjana have kaphagna, lekhaniya, rasayana property by which it reduces the thickness of Arma and helpful in further degeneration of tissue of conjunctiva. 
- Anti-oxidant property of Nayansukha varti anjana helpful in reducing the oxidation procedure of conjunctiva and presence of vitamin $\mathrm{C}$ in haritaki shows healing property, prevent haemorrhage which help in healing of epithelial tissue.
- Anti-oxidant property of Nayansukha varti anjana helps in maintain structural and functional integrity by arresting there occurance of hyperemia of Arma.

\section{PHARMACODYNAMIC ACTION OF NAYANSUKHA VARTI ANJANA:-}

\begin{tabular}{|l|l|l|l|l|l|l|}
\hline Dravya & Rasa & Guna & Virya & Vipaka & Doshaghnata & Karma \\
\hline $\begin{array}{l}\text { Pippali } \\
\text { (Piper } \\
\text { longum) }\end{array}$ & Katu & $\begin{array}{l}\text { Laghu, } \\
\text { snigdha, } \\
\text { ruksha }\end{array}$ & Anushnasheeta & Madhura & Vatakaphashamaka & $\begin{array}{l}\text { Deepana, } \\
\text { Hridya, } \\
\text { Rasayana }\end{array}$ \\
\hline $\begin{array}{l}\text { Haritaki } \\
\text { (Terminalia } \\
\text { chebula) }\end{array}$ & $\begin{array}{l}\text { Lavana } \\
\text { varjita }\end{array}$ & $\begin{array}{l}\text { Laghu, } \\
\text { Ruksha }\end{array}$ & Ushna & Madhura & Tridoshashamaka & $\begin{array}{l}\text { Medhya, } \\
\text { Chakshushya } \\
\text { Rasayana, } \\
\text { Shoolahara }\end{array}$ \\
\hline
\end{tabular}

\section{CONCLUSION:}

- Arma is shukla mandla gata vyadhi can be correlated with in modern science with Pterygium.

- Nayansukha varti anjana has significant effect in pacify the symptoms of Arma and marked reduction in clinical symptoms was well appreciated within treatment course.

- No adverse effect of drugs were observed during this course of study after administration.

- Statistical data on stated above has revealed significant result in reducing
Foreign body sensation, Photophobia, Ragta, Mamsa vridhi symtoms.

- Nayansukha varti anjana is proved to be cost effective, less irritant, safe and better drug for Anjana in Arma. Rasayan property of drugs helps in further degeneration of the tissue.

\section{REFERENCES-}

1. Sushruta samhita, Uttara tantra, Kaviraj Ambikadutta Shastri, Chaukhamba Sanskrit Sansthan, Varanasi, Edition-Reprint 2011

2. Ashtang hridyam, Uttara sthan, Kaviraj Atridev Gupta, 
ChaukhambaPrakashan, Varanasi, Reprint 2012

3. Bhavaprakasha Nighantu, Shri. BhavamishraCommentary by Dr. K.C. Chunekar, Edited by Dr. G.S. Pandey, Chaukambha Sanskrit Sansthan, Varanasi,4th Edition 1969

4. Chakradatta with padarth bodhini commentary by vaidya Ravidutta Shastri

5. Dravya Guna Vigyan, Acharya Priyavat Sharma, Chaukhambha
Bharati Academy,Varanasi.

Edition-2001.

6. ComprehensiveOphthalmology,

A.K. Khurana,New age international limited, 4th edition 2007.

7. Parsons' Diseases of the Eye, Ramanjit Sihota, Elsevier publication, $22^{\text {nd }}$ edition, 2011

8. Shailendra Barhate, Role of Guduchyadi Raskriyanjan in the management of Arma (Pterygium), Ayushdhara, July- aug2015, vol 2, issue $4,269-281$ 